\title{
“Kur palika Veidenbauma rokraksti?" (R. Egle)
}

\section{Lìvija Volkova}

\begin{abstract}
Kopsavilkums
Pētijjumā mēǵināts skaidrot, vai pēc Eduarda Veidenbauma nāves atrastie un pakāpeniski publicētie dzejoḷu manuskripti ir viss viņa dzejas mantojums vai tomēr palika vēl citi, līdz mums nenonākuši darbi. Pirmajā pētniecības posmā noskaidrota abu ievērojamāko Veidenbauma biogrāfu Edvarda Treimaņa-Zvārguḷa un Rūdolfa Egles attieksme pret šo jautājumu. Iznāca oponēt Veidenbauma draugam, skolasbiedram, pirmajam viņa biogrāfam Treimanim-Zvārgulim, kurš šādu problēmu ne tikai nav izvirzījis, bet netieši pat noliedzis iespēju tādai rasties. Pretējiem pierādījumiem citētas dažas saglabātās vēstules un atmiṇu pieraksti. Pētījumam par pamatu pieñemts Rūdolfa Egles problēmas uzstādījums, kaut gan viņš vairāk koncentrējies uz zināmo publicēto dzejoḷu pazudušajiem rokrakstiem. Tomēr skarts arī nezināmo dzejoḷu jautājums, un kopumā viṇa kapitālais darbs "Eduarda Veidenbauma Raksti" literatūrvēsturiskā un zinātniskā aspektā ir atbalsts katram pētniekam un tika izmantots arī šajā gadījumā. Kā izejas punkts pieteiktās problēmas tālākai risināšanai apskatīti "Kārḷa Veidenbauma Raksti”. Sniedzot nelielu kopsavilkumu par Eduarda Veidenbauma dzejas raksturīgākajām iezīmēm, akcentēta pārsteidzošā līdzība starp abu brāḷ Veidenbaumu - Kārḷa labākajiem dzejoḷiem un Eduarda dzejoḷiem. Savākti izvilkumi gan no "Rakstu" recenzentu atzinumiem, gan no agrākajiem presē publicēto attiecīgo dzejoḷu vērtējumiem. Tos visus vieno norādījums uz skaidri redzamo brāḷa ietekmi. (Runa ir tikai par ietekmi, radikālāku izteikumu nav.) Apvienojot konspektīvo dzejas formas analīzi ar visu triju brālu Veidenbaumu - Eduarda, Kārḷa, līdz šim maz pieminētā Voldemāra - un viņu draugu savstarpējo attiecību analīzi, izdarīts secinājums, ka ir pamats izvirzìt hipotēzi - Kārḷa Veidenbauma labākie dzejoḷi, kas parādās krasā pretstatā ar viņa pārējiem darbiem, ir plaǵiāts. Tos par pazudušiem uzskatītos Eduarda Veidenbauma dzejoḷu rokrakstus, kas bija nonākuši viņa rokās, viņš ir publicējis ar savu vārdu. Hipotēzes pārbaudei vēl nepieciešama vispusīga, skrupuloza aizdomīgo dzejoḷu pārbaude, analīze un konfrontācija ar Eduarda Veidenbauma dzeju.
\end{abstract}

Raksturvārdi: rokraksti, publikācijas, vērtējumi, brāḷi, hipotēze.

“Kur palika Veidenbauma rokraksti?" Šādu jautājumu Rūdolfs Egle licis 1926. gada monogrāfijas "Eduarda Veidenbauma Raksti" vienas nodaḷas virsrakstā. ${ }^{1}$ Kāda ir atbilde? Diemžēl pieejamais faktu materiāls ir bijis stipri nepilnīgs, vietām

${ }^{1}$ Eduarda Veidenbauma Raksti. Ed. Veidenbaums dzìvē un darbos. Bibliogräfiskas piezìmes. R. Egles redakcijā un sakopojums. Cēsis; Rīga: O. Jēpes izdevniecība, 1926, 690.-697. lpp. 
pretrunīgs. Literatūrzinātnieks reizēm ar skepsi izturējies pat pret dzejnieka drauga, pirmā viṇa Rakstu sakārtotāja un izdevēja Edvarda Treimaṇa-Zvārguḷa atminụu stāstījumiem. Pētījuma rezultātā ir radìts pārskats par saglabātajiem izziñas materiāliem, bet tie nevar dot drošu pamatu kādai noteiktai, neapstrīdamai atbildei.

Nekur tālāk nebijām tikuši arī pēc pusgadsimta, kad jaunā monogrāfijā atkal bija jāatgriežas pie Rūdolfa Egles darbam līdzīga nodaḷas virsraksta, proti, "Dzejnieka rokrakstu uzdotās mīklas". ${ }^{2}$ Izmantojot Egles iestrādes, mēǵinot izvilkt no krātuvēm vēl kādu aizmirstu rakstu, aina izveidojās drusku bagātīgāka, bet kopumā tikpat juceklīga. Mīklas netika atrisinātas, tikai iezīmēti daži virzieni, kādos nākotnē vajadzētu strādāt.

Jāuzsver, ka abās monogrāfijās meklējumu galvenais objekts ir tie rokraksti, kurus dzejnieks pats sakopojis burtnīcā (bērēs 1892. gada maijā tā gājusi no rokas rokā un palikusi pie viṇa studiju biedra Kārḷa Kasparsona) un kuru lielākā daḷa tikusi publicēta jau 1893. gadā "Dienas Lapā" un "Mājas Viesī", nedaudzi palikušie - pēc pāris gadiem. Vēlāk pazudušo oriǵinālu burtnīcu būtu bijis svarīgi atrast tāpēc, ka gandrīz katram 19. gadsimta beigās un 20. gadsimta sākumā iespiestajam dzejolim atkarībā no redaktoru gaumes ir tik variantu, cik publikāciju. Kaut gan zināmus pieturas punktus pirmatnējo variantu restaurēšanai ir devušas trīs vēl pieejamās 19. gadsimta 90. gados tautā aizgājušās dzejoḷu norakstu burtnīcas, tomēr tekstologíjas jomā joprojām ir palicis daudz neskaidrību. Norakstos vismaz ir saglabājušās dažas liecības par jaunā dzejnieka sava ceḷa meklējumiem dzejas formas aspektā.

Savukārt šā pētījuma objekts ir divās vēstulēs minētie ārpus publicētās burtnīcas esošie vēlāk, Tērbatā studiju pēdējo gadu laikā, tapušie Eduarda Veidenbauma dzejoḷu rokraksti. Dzejnieka draugs kopš Rīgas guberņas ǵimnāzijas laika, vēlākais studiju biedrs Pēteris Pīpkalējs raksta Voldemāram Veidenbaumam uz Cēsìm 1893. gada 24. septembrī:

Mīlais Veidenbaum! Atvaino, ka Tev tik vēl tagad Tava brāḷa dzejas piesūtu. Es reiz meklēju un neatradu, un domāju, ka esmu Tērbatā aizmirsis. Tik vēl tagad tās starp papīiem atradu. ${ }^{3}$

Veidenbaumu goimenes paziṇa un 1893. gada "Mājas Viesa” dzejoḷu publikāciju iniciators Pēteris Zālītis (kopš 1922. gada - Zālīte) raksta Kārlim vai Voldemāram Veidenbaumam 1895. gada 17. septembrī:

Cien. Veidenbauma kungs! Kā no Treumaṇa kga [tā laika rakstība L. V.] un arī Rīgā, ar Jums sarunādamies, dzirdēju, tad Jums vēl daži Edvarda [mājās Eduardu dažkārt mēdza saukt šādi - L. V.] raksti un dzejoḷi. Es Jums būtu l,oti pateicīgs un neizsakāmi priecātos, ja Jūs

\footnotetext{
${ }^{2}$ Volkova, L. Eduards Veidenbaums. Problēmas. Risinājumi. Hipotēzes. Rīga: Liesma, 1979, 31.-48. lpp.

${ }^{3}$ Eduarda Veidenbauma memoriālais muzejs "Kalāči”, CMK 602.
} 
man drīzumā piesūtītu Edvarda rakstus un dzejoḷus. Raudzìtu tos pēc iespējas ievietot "Mājas Viesa Mēnešraksta" pirmā burtnīcā [....$^{4}$

Uzruna “ Cien. Veidenbauma kungs!" adresātu neprecizē, bet aploksne ir pazudusi. Pēc 20. gadsimta otrās puses "Kalāču” muzeja vadītājas, dzejnieka māsas meitas Birutas Leites domām, vēstule rakstīta Voldemāram un tā muzeja reǵistros arī apzīmēta. Bet iespējams, ka Rūdolfa Egles darbības laikā aploksne vēl bijusi saglabāta, un l,oti ticams, ka viņš sava 1926. gadā izdotā darba "Eduarda Veidenbauma Raksti” 695. lappusē norādīto adresātu K. Veidenbaumu nav izdomājis, bet n,ēmis no tās. Ja taisnība būtu viṇam, tad atbilde uz jautājumu, vai Kārlim Veidenbaumam ir vai nav bijuši nelaik̦a brāla dzejoḷu rokraksti, būtu simtprocentīgi skaidra. Ja tomēr Pētera Zālīša vēstules adresāts būtu bijis Voldemārs Veidenbaums, tad šis pieņēmums saistās ar problēmu par Pīpkalēja sūtījumu.

Nekādi dzejoḷi ar Eduarda Veidenbauma vārdu ārpus zināmajā burtnīcā sakopotajiem neparādās ne "Mājas Viesa Mēnešrakstā", ne kādā citā izdevumā ne tajā laikā, ne vēlāk. Voldemārs Veidenbaums jau ap 1895. gada vidu, tātad pirms Pētera Zālǐša 17. septembra vēstules, bija pārcēlies pastāvīgā darbā uz Batumi pasta kantori.

Kādi varianti ir iespējami atbildei uz jautājumu, kur Voldemārs Veidenbaums aizbraucot lika līdz šim glabātos Eduarda Veidenbauma dzejoḷu rokrakstus?

Absolūti nelog̣iska šķiet doma, ka tie varētu būt aizvesti uz Kaukāzu. Pārāk ciešas savstarpējas sapratnes saites saistīja šos abus brāḷus, pārāk līdzịgi viṇi bija savos dzīves uzskatos un centienos pēc izvirzītā mērķa sasniegšanas, lai jaunākais brālis nesaprastu, ka nedrīkst šādus dzejoḷus izraut no dzīvās aprites. Savulaik izlasījis "Austrumā", ka Eduardam Veidenbaumam par rakstu "Apcerējumi iz mekānikas” pieškiirta prēmija, viņš 1892. gada 6. maija vēstulē aizkustinošā sirsnībā un uzspēlētā puiciskā nebēdnībā cer uzmundrināt Kalāčos gulošo, strauji progresējoša tuberkulozes procesa pārn,emto slimnieku, uzsaucot tam "Bravo bravissimo!":

[..] esi pierādījis, ka neesi vis kaut kādu niecīgu un nederīgu rakstu sacerētājs, bet goda algas cienīgs rakstnieks. [..] ieradǐšos "Kalāčos" un [..] sasitīsim glāzes uz ātru izvesel̦ošanos, krietnu turpmāku darbību latviešu rakstniecības laukā un uz eksakto studiju laimīgu pabeigšanu. ${ }^{5}$

(Voldemārs Veidenbaums sapn,oja pēc attiecīgas izglìtības iegūšanas savu mūžu veltīt tehniskiem izgudrojumiem.)

Ko gan log̣iskāku aizbraucējs varēja mīḷā nelaiḳa brāḷa labā izdarīt, kā atstāt manuskriptus Kalāčos otram brālim? Visi izdevēji taču zināja, ka noteicējs par Kalāčos palikušajiem dzejnieka dažāda satura rokrakstiem ir Kārlis Veidenbaums. Tulkojumus, apcerējumus viņš tiešām nodeva publicēšanai, bet, kad vēlāk - ap 90. gadu vidu - parādījās interese par varbūtējiem dzejoḷiem, viṇa attieksme dīvainā kārtā bija mainījusies. Uz to norādījis arī Rūdolfs Egle, nosaucot viṇu par

\footnotetext{
${ }^{4}$ Eduarda Veidenbauma memoriālais muzejs "Kalāči” CMK 604.

${ }^{5}$ Turpat, CMK 590.
} 
savādnieku, kurš par brāḷa rokrakstiem izsacījies diezgan skeptiski. Tātad šì dzeja ir tik slikta, ka tā arī nevienam netika dota...

1896. gada sākumā Veidenbaumu gimeni pēc Eduarda nāves piemeklēja jauna nelaime - no Batumi sāka pienākt vēstules, kas atklāj dramatisku ainu. Voldemārs ir saslimis ar "grūtu krūšu slimību" un janvāra beigās ārstēšanās vajadzībām lūdz Kārli steidzami atsūtīt 75 rubḷus. 6. februārī seko atkārtots lūgums, 1. martā no kara slimnīcas nākamais. Pēc ilgās kavēšanās nauda beidzot pienāks, tikai tad tā vairs nebūs vajadzīga. 1896. gada 15. martā Voldemārs Veidenbaums divdesmit četru gadu vecumā mirst.

Brāḷu Veidenbaumu draugs Edvards Treimanis-Zvārgulis, zinādams, ka arī vecākais brālis ir mēginājis nedaudz dzejot, uzaicināja viṇu dot savus dzejoḷus iecerētajam krājumam "Dzejas pūrs" (1897). Saṇēmis piekrišanu, gan it kā negribīgu, "Pūra" sastādītājs raksta:

Rīgā, 18. nov. 96. g. Mīlais Veidenbaum! No Taviem dzejoḷiem es varēšu uzṇemt gabalus 13. Arī dzejoli "Sēž pie ratiņa meitene maza" izlietošu. [Publikācijā: "Redz pie ratiņa meiteni sārtu". - L. V.] Es vinuu pēc iespējas nogludināju, un tagad tas skan l̦oti dailii. Visas atskan,as "klapē" uz labāko. Sestdien bija pie manis Teodors [Teodors Zeiferts - L. V.] [..]. Viņš arī Tavus dzejoḷus izlasīja un izteicās par tiem visai atzinīgi. [..] Tâ tad, kā redzi, Tu ar vienu rāvienu būsi mūsu labāko dzejnieku rindā, kur citam jāmocās ilgi gadi. [..] Tavs uzticamais E. Treumans. ${ }^{6}$

Edvards Treimanis patiesi Kārlim Veidenbaumam ir uzticams palīgs un arī turpmāk, labu gribēdams, cītīgi "gludina" drauga pantus, likdams lietā savu pieredzi. Šajā laikā, 90. gados, viņš, Zvārgulu Edvards, bija viens no populārākajiem dzejniekiem, piedevām ilgstoši nodarbojies ar dažādu izdevumu sastādīšanu un redigéšanu. Rūdolfs Egle, gatavodams monogrāfijas par Kārli Veidenbaumu (1925) un Eduardu Veidenbaumu (1926), ir salīdzinājis vecākā brāḷa publicētos dzejoḷus ar Kalāčos vēl atrodamajiem rokrakstiem un secinājis - Treimaņa redakcionālā iejaukšanās oriǵinālos ir gājusi tiktāl, ka vietām notikusi pat veselu rindu "pārdzejošana".

Diezgan daudzi Kārḷa Veidenbauma dzejošanas mēǵinājumi bijuši tik vāji, ka pat Treimanis to atzinis un atstājis nepublicētus, jo tur nekas nav bijis saglābjams. Tomēr laika periodā no 1897. gada līdz šā maz ievērotā dzejnieka nāvei 1901. gadā, kad vinš̌ pa retam nāca klajā "Mājas Viesa" pielikumā un "Mājas Viesa Mēnešrakstā", parādījās arī īsti spēcīgi, ievērības cienīgi dzejoḷi. Taču nekādu atsauksmju nebija, izņemot Teodora Zeiferta teikumu pārspriedumos par Eduardu Veidenbaumu "Dzejas pūra" ievadrakstā "Latviešu lirikas attīstība": "Kaut kas līdzīgs no Eduarda Veidenbauma skan arī viṇa brāḷa Kārḷa V. dzejoḷos."”

${ }^{6}$ Eduarda Veidenbauma memoriālais muzejs "Kalāči", CMK 613.

${ }^{7}$ Dzejas pūrs. Oriǵināldzejoḷu krājums, Zvārguḷu Edvarda sakārtots. Ar atskatu par latviešu lirikas attīstību no Teodora un tulkotu dzejoḷu pielikumu. Cēsis; Vecpiebalga: J. Ozols, 1897, 22. lpp. 
Nākamā īsā piezīme, atkal abu brāḷu salīdzinājumā, atrodama Kārḷa Veidenbauma nekrologā:

Veidenbauma dzejā redzam, tāpat kā viṇa nel. brāḷa dzejā, pa lielākai daḷai nopietnus, drūmus dzīves uzskatus, ilgas pēc kaut kā nenoteikta un nemieru ar sevi un dzīvi. Taču dažreiz parādās arī liels spars, pa reizei pat humors un satīra. ${ }^{8}$

Pirmo izvērsto recenziju sakarā ar Kārḷa Veidenbauma Kopoto rakstu iznākšanu 1911. gadā rakstījis Kārlis Krūza:

[D]zejā viņa zināšanas bij l,oti trūcīgas un spējas aprobežotas, kāpēc grūti viņu par dzejnieku atzīt. [..] Lielāku iespaidu var atstāt "Darbs", "Raidi pie joda tu tumšajās domas" (Eduarda iespaids) un "Tam vajga tā būt!". Pēdējais gabals rakstīts stiprā sajūsmā un turas patiesas dzejas augstumā. [..] No trešās nodaļas dzejoliem būtu atzīmējami - "Mūžìgais laiks", "Kaut zvaigzne, kuru es redzu", "Divas rozes" [Rūdolfs Egle vēlāk noskaidroja, ka tas ir Edvarda Treimaṇa-Zvārguḷa pārdzejojums. - L. V.] un "Pie debess, kur zvaigznes var ieraudzīt", starp kuriem "Pie debess, kur zvaigznes var ieraudzīt" radies laimīgā brīdī, kad arī Kārḷa Veidenbauma dvēseli aizskāruse "kā vēsma no mūžīgās dzejas". [..] Visā krājumā tātad atrodam ap 10 dzejoḷus, kuru dēl galīgi atmest Kārli Veidenbaumu nevar. ${ }^{9}$

Visplašākā atsaucība izskan 1925. gadā sakarā ar Rūdolfa Egles sastādītajiem Kārḷa Veidenbauma "Rakstiem", kur pievienota arī dzejnieka biogrāfija. Pēteris Ērmanis:

Kārḷa Veidenbauma darbus “[..] vietām apskaidro spožas dzejas gaisma. Brāla Eduarda iespaids nepārprotams un nenoliedzams, bet ir arī kaut kas ìpatnējs un savs. [..] Veidenbaums kā prātnieks spēj pasaules laimes un nelaimes, laba un l̦auna mūžīgā maiṇā redzēt dievišķu likumību un saskaṇu, kā tas izjūtams skaistajā dzejolī "Tam vajga tā būt!"."10

Andrejs Upīts: “Treumaṇa un it sevišķ Ed. Veidenbauma iespaidi katram nepārprotami izmanāmi." 11 Arturs Baumanis: "Ir pat bijuši gadījumi, kur Kārḷa Veidenbauma populārākie dzejoḷi (piem., "Redz pie ratina meiteni sārtu") apzīmēti kā Eduarda Veidenbauma sacerēti. [..] Uz viṇa liru atstājusi lielu iespaidu brāḷa un Ed. Treuman,a dzeja."12

\footnotetext{
${ }^{8}$ Dienas Lapa, 1901, Nr. 261, 15. nov.

${ }^{9}$ Latvija, 1911, Nr. 279, 3. dec.

${ }^{10}$ Latvju Grāmata, 1925, Nr. 6, 438. lpp.

${ }^{11}$ Domas, 1925, Nr. 8, 226. lpp.

${ }^{12}$ Latvis, 1925, Nr. 1269, 22. dec., 4. lpp.
} 
Kārḷa Veidenbauma biogrāfs un vina "Rakstu" veidotājs Rūdolfs Egle sava aprakstāmā autora vērtējumos ir nedaudz pretrunīgs - ievadā vispārējos vilcienos pat l,oti atzinīgs, noliedzot viņa aplūkošanu "tikai Eduarda Veidenbauma un citu devin, desmito gadu dzejnieku atgaismā. Savas pārdomas viņš ir izteicis ar lielu skaidrību, lakoniski, nejuzdamies saistīts ar valdošiem literāriskiem virzieniem. [..] Pasauli viņš uzlūkoja ar domātāja skatu, ar apceri, kā prātnieks uzlūko noslēpumaino zvaigžņu mirdzumu."13

Tālāk pievēršoties konkrētākai analīzei un atgādinot, ka dzejniekam jāpārvalda valodas līdzekḷi un vienības devēja forma, Egle aizrāda par neizstrādātiem darbiem:

Stila vienība un nevainojama izteiksme ir tikai dažām K. Veidenbauma dzejām: "Tam vajga tā būt", "Redz pie ratiņa meiteni sārtu”, "Viss grozās un kustas", "Lai aug uz kapa man nātres", "Un viņa man pieglaužas klātu”. [..] Tieši viņa dzejā no latviešiem vislielākā saskatāma Ed. Veidenbauma un Treumaña tuvība. ${ }^{14}$

Visi minētie recenzenti pārsteidzošā vienprātībā ir uzsvēruši brāla ietekmi vienā dal̦ā Kārḷa Veidenbauma darbu. Priekšstata radīšanai neliels ieskats praktiski nepazistamajā un gandrīz par bibliogrāfisku retumu kḷuvušajā dzejas krājumā sniegts raksta beigās pievienotajā pielikumā "Kārḷa Veidenbauma dzejoḷi", kas papildināts ar īsām piezīmēm.

Grūti saprast, kā viens autors ir spējīgs rakstīt tik radikāli atškirīgos rokrakstos. Plaisa starp abām dzejoḷu grupām, otrajai vēl pieskaitot muzejā glabātos nepublicētos, resp., nepublicējamos darbus, ir milzīga. Tādēḷ, lasot vienprātīgo spriedumu par brāḷa ietekmi, rodas sajūta, ka tomēr nav pateikts viss līdz galam.

Viens no dažādiem varbūtējiem apstākḷiem, kādēl uzkrītošās līdzības konstatējumi nerosināja pārbaudīt, vai te gadījumā nav darīšana ar plağiātiem, bija Eduarda Veidenbauma pirmā biogrāfa Edvarda Treimaņa-Zvārguḷa izteikumi, ka viss mums zināmais ir sarakstīts līdz 1889. gadam un kopš 1890. gada viņš nav vairs dzejojis. Būtu jāsecina, ka tātad nekā nezināma viṇa daiḷrades mantojumā nevar būt.

Bet tam, ka kaut kas nezināms tomēr pastāv, līdzās Pētera Zālīša 1895. gada 17. septembra vēstulei mums ir vēl kāds liecinieks. Kopš Eduards Veidenbaums bija prom Tērbatā, agrāko gadu drauga, Cēsu skolasbiedra Treimaṇa vietā vin,am radās citas, būtībā garīgi dziḷākas saites ar dažiem studiju biedriem, īpaši ar Aleksandru Daugi. Un Dauge savās biogrāfiskajās apcerēs ir uzsvērti apgalvojis, ka Eduards Veidenbaums, pēc savas garīgās struktūras būdams îsts dzejnieks, nekad nav pārtraucis dzejot. Kā apstiprinājums šim apgalvojumam ir jau minētie Pīpkalēja saglabātie dzejoḷu rokraksti - risināmās problēmas galvenā atslēga.

\footnotetext{
${ }^{13}$ Kārḷa Veidenbauma Raksti. R. Egles redakcijā ar dzejnieka biogrāfiju. Cēsis; Rīga: O. Jēpes izdevniecība, 1925, 5. lpp.

${ }^{14}$ Turpat, 34. un 35. lpp.
} 
Sastatot visus līdz šim minētos, literatūras vēsturē saglabātos faktus ar raksturīgākajiem aizdomas raisošajiem, resp., Eduarda Veidenbauma toṇkārtā skanošajiem dzejoḷiem, ir pamats izteikt hipotēzi: Kārlis Veidenbaums ir publicējis gan savus, gan ar savu vārdu arī Eduarda Veidenbauma dzejoḷus.

Pagaidām iezīmējami tikai lielās līnijās galvenie pieturas punkti hipotēzes tālākai analīzei. Pirmkārt, tas ir Eduarda Veidenbauma daiḷrades īpatnību atgādinājums, ar Kārla Veidenbauma vārdu publicētos iepriekš norādītos piemērus atstājot vienīgi ieskatam, pirmajam salīdzinājumam. Visbūtiskākā Eduarda Veidenbauma leksikas pazīme ir abstrakto jēdzienu lielais īpatsvars, kas nosaka dzejas augsto vispārinājuma pakāpi: mūžs, mūžīgs, laiks, dzīve, dzīvība, jaunība, laime(-ība), prieks, cerības, raizes, veltīgi, liktenis, nāve, cilvēks, prāts, pasaule, zeme, dvēsele (tās nozīmē arī sirds, krūtis) u. c. Dzejas tēlu kompozīcija bieži veidota pat l,oti krasos pretstatos: bezgalīgais mūžības laiks un cilvēkam atvēlētais skaudīgais laiks; cerības, sapn,i un nežēlīgais liktenis; varmākas, blēži un ārprātīgie, "pie sirds kam kneras šì bēdu luga” u. c. Sintakses jomā raksturīgi, ka pants, retāk pat viss dzejolis, ir viens izvērsts salikts teikums. Šai dzejai piemīt īpaša aktivitāte - absolūtā pārsvarā tā veidota kā uzruna, aicinājums, pavēle, ieteikums, ironiskais ieteikums, pārmetums, vēlēšanās. Tādā aspektā darbojas arī bieži sastopamā partikula "lai". Dzejas ritmikā raksturīgi trijzilbnieki (amfibrahijs un daktils) un dažkārt ritmu dažādošana viena panta robežās. Ar pāris izṇēmumiem dzejol̦iem nav virsrakstu.

Kārḷa Veidenbauma "Rakstos" publicētajos labākajos dzejoḷos šīs pazīmes ir labi saskatāmas. Bet, protams, vēl daudz un pamatīgi analizējamas. Pien,emot varbūtību par Kārḷa Veidenbauma izmantotajiem brāḷa rokrakstiem, rodas dažas pārdomas tīri psiholoǵiskā plāksnē. Kādi apstākḷi varēja pamudināt viṇu uz šādu rīcību?

19. gadsimta 90. gados vēl joprojām valdīja nevērība pret autora tiesībām. Redaktori, dažkārt arī cenzoru spiesti, svītroja, laboja, kā to, piemēram, pieredzēja arī Kārlis Veidenbaums, kad Edvards Treimanis "gludināja" viṇa darbus. Bieži drukāja lokalizējumus un tulkojumus bez norādēm uz pirmavota autoru. 1898. gadā, recenzēdams "Dzejas pūru”, Ermanis Pīpiņš-Vizulis izsaka cerību, ka tur visi dzejoḷi patiešām esot oriğināli, kaut gan droši zināt nevarot, jo "tulkojumu nostādīšana par oriǵināliem vēl arī tagad ir pie mums parasta lieta". ${ }^{15}$

Eduards, saṇēmis ǵimnāzijas laikā un studiju pirmajos gados no brāḷa kā Kalāču mantinieka vecāku noteiktos viņam izmaksājamos 500 rubḷus, sākot ar 1889. gadu, kā Aleksandrs Dauge to norāda, "bija cietis vislielāko trūkumu, bija dzīvojis kā pēdējais nabags, salis un badojies, un nezinājis, ko vilkt mugurā". ${ }^{16}$ Vinš̌ gan pats centās kaut drusku nopelnīt, bet galvenokārt bija spiests taisìt parādus. Ar domu, ka pēc universitātes beigšanas tos pamazām atmaksās. Tādas attiecības vin,am izveidojās arī ar Kārli, no kura viņš, ik pa laikam lūgdams palīdzību, bija papildus saṇēmis ap 200 rubḷu. 1890. gada 2. septembrī viṇš brālim raksta:

${ }^{15}$ Jauna Raža, I. Cēsis; Vecpiebalga: J. Ozols, 1898, 187. lpp.

${ }^{16}$ Dauge, A. Raksti. Kultūras ceḷi, II. 2. sēj. Cēsis; Rīga: O. Jēpes izdevniecība, 1925, 213. lpp. 
Ja Tu vari, tad atsūti man vēl kādus 7 rubḷus, es domāju, ka tā būs pēdīgā reiza, kad no Tevis ir jāprasa nauda, ko Tu jau man esi pāri par iespēju devis; uz priekšu tevis vairs neapgrūtināšu, bet pēc studiju beigšanas ar visiem spēkiem centǐšos Tev atlīdzināt Tavus izdevumus. ${ }^{17}$

Bet Eduards Veidenbaums aizgāja, palikdams brālim parādā...

Draugs Edvards Treimanis nāk ar vilinājumu publicēties. Kalāču saimnieks ir pietiekami spējīgs spriest, lai saprastu, ka bez brāla "palīdzības" iznākums var būt visai bēdīgs. Kas attiecas uz Pētera Pīpkalēja sūtījumu, tad tam ir bijuši divi aculiecinieki, kas varētu dzejoḷus publikācijā atpazìt. Tagad viens ir miris, otrs tālu prom no Latvijas un atgriezties nedomā. 1895. gadā pabeidzis Tērbatā Teolog̣ijas fakultāti, Pīpkalējs ir mācītājs vācu kolonijās Saratovā un Tbilisi apkaimē, vēlāk Kaukāza kara apgabalā luterāṇu konfesijas garīdznieks.

Lai kādi arī būtu iespējamie "cilvēciskie faktori”, tie visi ir tikai minējumi, kam nav pierādījumu. Atstājot tos kā papildinājumus hipotēzes risināšanai, jāgriežas pie reāliem pierādījumiem, resp., pie literatūrzinātnes. Jauni, analītiski pētījumi visos iespējamos rakursos vienīgie varētu sniegt atbildi uz provokatīvo jautājumu: vai daḷa it kā pazudušo Eduarda Veidenbauma dzejoḷu ir tikuši publicēti ar Kārḷa Veidenbauma vārdu?

\section{Pielikums}

\section{Kārḷa Veidenbauma dzejoḷi}

Vērtētāju visvairāk pieminētais un Kārḷa Krūzas izteikumā patiesas dzejas augstumu sasniegušais dzejolis "Tam vajga tā būt!":

Tam vajga tā būt, lai pasaules rodas, Lai mūžīgi kustas un griežas, un zūd, Lai dzīvības ceḷas, lai aug un lai zaḷo, Lai mainās un beidzas, un iznīkst un trūd.

Tam vajga tā būt!

Tam vajga tā būt, lai varenā saule No augšienes starus uz pasaules sūt, Lai uztura pasaulē dzīvības dzīvas, Lai viņas attīstās, domā un jūt.

Tam vajga tā būt!

${ }^{17}$ Eduarda Veidenbauma Raksti, 673.-674. lpp. 
Tam vajga tā būt, lai dzīvība katra

Bez rimšanās cīnās sev uzturu gūt,

Un mīlē un nīstas, un karo un tiesā:

Šim vajag celties, tam vajag grūt.

Tam vajga tā būt!

Tam vajga tā būt, lai dzīvību prāti

Pie sevis apkārtnes iespaidus jūt,

Pēc tiem lai vēro labu un launu,

Lai uzstāda mērķus, ko vēlas sev gūt, -

Tam vajga tā būt!

Tam vajga tā būt, lai cilvēks to dara,

Ko saka prāti, ko dvēsele jūt.

Stāv prāti un jūtas zem augstajās varas...

Viss tas, kas notiek, tam vajga tā būt! -

Tam vajga tā būt! ${ }^{18}$

Ar šo dzejoli sasaucas tikpat izstrādātā formā un domas dziḷmā veidotais "Mūžīgais laiks".

Mūžìgais laiks!

Jel parādi vienreiz man laimības vietu

Un teic, kurp lai dzīvojot teka man ietu!

Vai cel̦š nava staigs?

Mūžìgais laiks!

Es pasauli zinu tik aukstu un cietu.

Mūžìgais laiks!

Tu saki, ka šeitan mūs sagaida prieki.

Kam māni tu mani tā veltīgi, lieki?

Cik tukšs un baigs!

Mūžìgais laiks!

Es jūtu un redzu, ka viss še ir nieki.

Mūžìgais laiks!

Gan strādāju cītīgi smagajo darbu, Bet jūtu tik likteni l,aunu un skarbu, Man drūmīgs ir vaigs!

Mūžìgais laiks!

Ko mantoju? - ubaga spiek,i un tarbu! ${ }^{19}$

${ }^{18}$ Kārḷa Veidenbauma Raksti, 43. lpp.

19 Turpat, 46. lpp. 
Recenzentu nepieminēts, bet l,oti veidenbaumiski skanošs ir dzejolis "Nākamība miglā tīta":

Nākamība miglā tīta,

Cerība tik spēkus dod.

Tūkstošiem redz skumjās vaidot, Laimīgs tas, kas dzīvot prot.

Kas pēc košas rozes gūsta,

Arī asos ērkšķus jūt;

Un, ja kādam prāts par mazu,

Lūgšanas uz augšu sūt.

Dienas nāk, un dienas beidzas,

Cilvēks pūlas, mīlē, nīd,

Kamēr izdziest dzīves svece,

Aukstās miesas kapā slīd. ${ }^{20}$

Nopietnu vērību pievēršot tieši dzejnieka, turklāt erudītā dzejnieka, Kārḷa Krūzas izvirzītajiem piemēriem, dzejolis "Pie debess, kur zvaigznes var ieraudzīt":

Pie debess, kur zvaigznes var ieraudzìt, Tur mūžīgās gaismas mājokḷi mīt, Aust vienumēr saule un vienumēr riet, Bet cilvēkam jaunība vienreiz tik zied.

Gan gaudo vēji, gan vēsmiņa glauž, Drīz atmostas daba, drīz mierīgi snauž, Un gadi pēc gadiem šeit mīdamies iet, Bet cilvēkam jaunība vienreiz tik zied.

Iz tumšajiem avotiem ūden,i plūst, Ar plašajo jūru tie vienoti kḷūst, Steidz vilnis gar vilnīti mūžīgi skriet, Bet cilvēkam jaunība vienreiz tik zied.

Lai tādēḷ, pirms vecuma grūtības spiež, Pirms nāve pret krūtīm izkapti griež, Ikkatris līksmo un skūpsta, un dzied, Jo jaunība cilvēkam vienreiz tik zied. ${ }^{21}$

${ }^{20}$ Kārla Veidenbauma Raksti, 47. lpp.

${ }^{21}$ Turpat, 49. 1pp. 
Ar saturiskajiem pretstatiem saistīto ritma maiṇu, kas raksturīga vienīgi Eduardam Veidenbaumam, uzmanību pievērš dzejolis "Kad dzīves laivu svaida...":

Kad dzīves laivu svaida

Pa bangām liktenis

Un vētras gaudo, vaida, Pūš asais ziemelis, -

Tad tici jel droši: ar negaiss reiz stāj,

Un ziedonis, laime un līgsmība māj.

Kad l̦aunas l̦aužu mēles

Raug dzīvi rūgtināt

Un mēlnesību kvēles

Drīz priekus samaitāt, -

Tad dziedi vien jautri, - lai bēdājās cits -

Tik mul,ki un geksi vien mēlnešiem tic! ${ }^{22}$

Pat bez recenzenta norādījuma uz brāla ietekmi, lasot dzejoli "Raidi pie jodiem tu tumšajās domas", nevar nedomāt par mums tik pazīstamajām nebēdnīgajām intonācijām vairākos Eduarda Veidenbauma dzejoḷos:

Raidi pie jodiem tu tumšajās domas,

Beidzi par dzivi reiz sēroties.

Tēlo tik pasaulē priecīgas lomas,

Desmitkārt dzīvot tad patiksies.

Visu, ko māmuḷa daba tev dāvā,

Izlietot mudīgi pasteidzies,

Spiest pie krūtīm ja meiču tā l̦āva,

Kādēḷ tad ilgāki vilcinies?

Nebaidies niekus! Tik mullki vien baidās,

Murgo un ziedo daudz asaras,

Allaž tie nododas rūpēs un vaidās,

Cerē uz prieku, kad nebūs vairs tas.

Netici blēņām! Tik dzīvē ir prieki,

Nomiris sastāvā pārvēršas.

Atmiņas, jūtas un dvēseles spēki

Mirušam cilvēkam izgaistas. ${ }^{23}$

${ }^{22}$ Kārla Veidenbauma Raksti, 75. lpp.

${ }^{23}$ Turpat, 62. lpp. 
Krājumā sastopami arī laucinieku ikdienišksas tematikas dzejoḷi.

\section{Aust diena}

Aust diena...

Jau vecais ar keras pie balsta,

Dzen zirgu uz vagu un saīdzis glūn,

Kā lemeši velēnas valsta.

Ir tvīkstoša diena; sāk dunduri dūkt,

Ap zirgu un arāju skraida,

Tie meklē, kur varētu asinis sūkt,

Zirgs tramdās un arāju svaida.

Ir celmāja jāar, darbs nomocošs, grūts,

Pa siekstēm un saknēm iet vaga.

Pil vecajam sviedri; iz elsošās krūts

Tam izvel̦as nopūta smaga:

"Pie joda, cik grūti! Kad biju vēl jauns,

Šāds darbs man bija pa joku;

Kur tagad es vecs, nu visiem es l̦auns,

Man dzive it pilna tik moku.

Man prasīja spēku, es devu ar to,

Tak spēks iz manis reiz sīka;

Maz tādu, kas mani nu ievēro,

Mans spirgtums caur pūlēm tik nīka.

Ne arkla, ne zirga, ne lauka man nav,

Tie pieder citam - es aru;

Daudz postažas druvās es pārvērsu jau;

Es laimīgs, ja paēst tik varu.

Sāp kauli, un nespēkā sen jau es grimis,

Tak manim vēl lika šo celmāju plēst...

Nekas, nekas, priekš darba es dzimis,

Bet nelaime tikai - nav šodien ko ēst." ${ }^{24}$

\section{Ganiňš}

"Dēlin, celies augšā aši,

Meitas kūtī govis slauc,

Vārti atcelti ir plaši,

Saiminiece tevi sauc!"

"Māt, vēl drusku gulēt gribu!"

"Ne, nav laika, dēlin, nav!

Lūk, še ielieku tev cibu,

Celies, celies, kājas aun.”

${ }^{24}$ Kārḷa Veidenbauma Raksti, 44. lpp. 
Miegu berž iz acīm laukā, Mazais cilvēks, sag̣ērbjas, Savus suṇus kopā saukā, Aizdzen lopus ganībās.

Rasas piles zālē zvīḷo, Tīrais balzams gaisā ož. Lopi plavas malu mīḷ, Pilnām mutēm zāli kož.

Saule spīd, un lopi ganās, Mazam acis cieti slīd. Lopi tālāk pḷavā manās, Kamēr pašā vidū mīt.

Saimnieks arī drīz ir klātu, Redz, ka zēns tur saldi dus, Tad ar saīgušu prātu Lauž no bērza žagarus. ${ }^{25}$

\section{Izstādē}

Kapsētā nu svētkus svin, Visa apkaime to zin. L,aužu bari kopā steidzas, Visiem soḷi labi veicas. Drūzma satek Liepin̄ās. Draugs ar draugu satiekās. Mācītājs tik formas pēc Atnākt kapsētā ar mēdz, Jo it maz to uzklausa, Tikai l,audis apskata. İsti ņem šos svētkus vērā Jaunkundzītes lielā mērā: Izpērk tukšas visas bodes, Lai tik uzpostos pēc modes. Cepures ar strausa spalvu Apsedz vin̄ām viegli galvu. Kleitas drēbe izietas Trīsi desmit aršinas. Saules širmis, glazē cimdi, Brošu, gredzenu daudz simti, Bārkstes, pušķi, šallītes,

${ }^{25}$ Kārḷa Veidenbauma Raksti, 78. lpp. 
Fraņas, špices, krellītes.

Un, kad labi noskatas,

Viss pēc vācu glītības...

Tur tās staigā lielos baros,

Nāk uz mājām strēķos garos,

Staigādamas patērzē:

"Šodien bijām izstādē!"26

\section{“Where did Veidenbaums's manuscripts remain?" (R. Egle)}

\section{Livija Volkova}

The research aims at clarifying whether the manuscripts of poems found and gradually published after the death of Eduards Veidenbaums are the entire legacy of his poetry, or whether there are still other works left that have not reached us. The first stage of the research focuses on the stance taken by the two most prominent biographers of Veidenbaums - Edvards Treimanis-Zvārgulis and Rūdolfs Egle. The research findings disagree with the opinion of Veidenbaums's friend, schoolmate, and first biographer Treimanis-Zvārgulis, who denied the very possibility of unknown works. Some preserved letters and memoirs are cited as evidence to the contrary.

The research is based on Rudolf Egle's considerations, who though mostly focused on the missing manuscripts of known published poems, still raised the issue of unknown poems. Moreover, his monolithic work Eduards Veidenbaums's Writings would aid any researcher in literary studies and as such was used in the present research as well. Writings of Kārlis Veidenbaums is considered as a starting point for further analysis of the identified problem. Giving a brief summary of the most characteristic features of Eduards Veidenbaums's poetry, a striking similarity between the poetry of two brothers Kārlis Veidenbaums and Eduards Veidenbaums - is emphasized. The excerpts have been collected both from the critique offered by the reviewers of Eduards Veidenbaums's Writings and from previous evaluations of the poems published in the press. They unanimously refer to the brothers' obvious influence. (It is only about influence, there are no more radical statements.) The summative analysis of the poetic forms combined with the analysis of the relationship between all three Veidenbaums brothers - Eduards, Kārlis, and the rarely mentioned Voldemārs and their friends, allows to conclude that Kārlis Veidenbaums's best poems, which stand in stark contrast to his other works, are plagiarism. He published the manuscripts of Eduards Veidenbaums's poems, which were considered lost and had fallen into his hands, under his own name. The validation of the set hypothesis requires a comprehensive, scrupulous examination and contrastive analysis of suspicious poems with the poetry of Eduards Veidenbaums.

Keywords: manuscripts, publications, evaluations, brothers, hypothesis.

${ }^{26}$ Kārḷa Veidenbauma Raksti, 79. 1pp. 